\title{
Analysis of Effect of Organization Commitment, Microfinance and Accountability on Poverty Reduction in the Farmers
}

\author{
Nursito, Dewi Faeni
}

\begin{abstract}
This study aims to examine the effect of organizational commitment, microfinance and accountability on poverty alleviation. The study was conducted on 320 respondents from a population of 450 members in a farmer group in the northern coastal area of West Java. The questionnaire test was also conducted on 64 respondents before the research was conducted. The analysis model uses Structural Equation Model (SEM)

The results revealed that both simultaneously and partially organizational commitment, microfinance and accountability have positive and significant impacts on poverty alleviation of farmer groups in the north coast of West Java.
\end{abstract}

Based on the empirical findings of this study, accountability in farmer groups in the northern coastal area of West Java should be improved, to enhance the organization's commitment, organizational commitment to the first critical determinant and microfinance of the second important factor

\section{Background}

Acceleration of poverty reduction strategy as regulated in Presidential Regulation of the Republic of Indonesia no. 15 Year 2010 on the Acceleration of Poverty Reduction can be done in several ways such as through improving the ability and income of the poor and developing and guarantee the sustainability of micro and small business [14].

Based on the facts, poverty is still a big problem for the Indonesian nation. One of the causes of poverty in Indonesia is the fundamental problem facing farmers is the lack of access to sources of capital, markets and technology, and farm organizations are still weak. Therefore poverty reduction is part of the implementation of long-term development plans and global agreements to achieve the Millennium Development Goals [5-7].

Capital management cannot be separated from poverty reduction efforts. Even the attention and effort to develop microfinance is primarily based on organizational commitment to poverty reduction efforts [8-10]. This is what underlies the various international institutions that move directly in poverty alleviation activities [11].
Poverty alleviation can be implemented through many facilities and programs either directly or indirectly. This effort

can be in the form of transfer payment from government for example, food program, health, settlement, education, family planning, and productive business such as through micro credit loan [12-17].

More and more parties are coming to believe that the financial and microcredit mechanisms are an important strategy in managing poverty that is managed accountably [18-22]. The proof is central and local government, as well as private institutions are busy distributing revolving funds to community groups through financial institutions and micro credit (LKM) [23-27].

Achieving the goals of a large company and small companies to run effectively and efficiently needed organizational commitment, capital and human resource accountability that can manage properly and correctly so that the level of poverty to be reduced. Members have a very important role in the success of an organization within the farmer group [28-32]. The better the ability possessed by a farmer's group then of course his work performance will increase so that it can directly assist in advancing a farmer's group [33-35].

\subsection{Formulation of the problem}

From the above background then the problems in this study are:

Is there any influence of organizational and microfinance commitment to accountability either partially or simultaneously?

Is there any influence of organizational commitment, microfinance and accountability towards poverty alleviation either partially or simultaneously?

\subsection{Research purposes}

The purpose of this study intends to know and analyze:

$>$ The influence of organizational commitment and microfinance on accountability either partially or simultaneously

$>$ The influence of organizational commitment, 
microfinance and accountability towards poverty alleviation either partially or simultaneously

\section{THEORY REVIEW}

\subsection{Poverty}

Poverty is a fundamental problem experienced by many developing countries. The level of poverty and food security has a linkage, ie the higher the poverty level of the households, the lower the food security. The policy implication is to strive to increase household business diversification in the absence of income-generating employment. Wirawan et., al (2015). poverty is a shared responsibility not just the responsibility of the government alone. The causes of poverty as interrelated causal relationships hook into a vicious circle between powerlessness, poverty, vulnerability, physical weakness, and isolation. Separating the poverty chain is an effort that is considered to free the poor from helplessness so that it grows power and has economic independence. Chambers (2013).

\subsection{Organizational Commitment}

Commitment is an individual attitude towards the organization in carrying out its main duties and functions. "as state in which an employee identifies with a particular organization and its goals and wisges to maintain membership in the organization". (Witt. 2008)

Commitment is a feeling of identification, loyalty and involvement shown by the worker to the organization or involves three attitudes: 1) feeling of identification with organizational goals; 2) feelings of involvement in organizational tasks; and 3) feelings of loyalty to the organization. Lack of commitment can decrease organizational effectiveness. A committed person can not get out and receive another job. (Wibowo)

Thus, high replacement costs do not occur. Besides that people are committed and highly skilled require little supervision. Rigorous monitoring and rigid monitoring monitoring processes are time-consuming and costly. Furthermore, committed people feel the value and importance of integrating individual and organizational goals.

Commitment "as the desire on the part of an employee to a member of organization". (Colquitte et. al.,)

Revised Manuscript Received on July 05, 2019

Nursito, ${ }^{2}$ Faculty of Post Graduate, Universitas Budi Luhur, nursito@budiluhur.ac.id unit of the organization. Commitment to the organization

\subsection{Microfinance}

Microfinance institutions are institutions that provide financial services to low-income residents and are among the poor. This microfinance institution is specific because it meets the demand for funding of the poor on the availability of funds. Microcredit summit (1997) Microcredit is a small lending program to the poor to finance productive activities done alone to generate income, enabling them to care for themselves and their families (Wijono 2005), Empowerment of Microfinance Institutions including informal financing institutions appropriate steps in efforts to alleviate poverty and economic development of the people (Nurmanaf 2007 in Yopi et al., 2011). As a provider of funds for farmers, informal institutions are considered very flexible and relatively accessible because they do not require complex administrative procedures as well as formal financing institutions.

\subsection{Accountability}

Accountability is the condition of a person who is judged by others because of the quality of his performance in completing the task to achieve the objectives he is responsible for. Minarti (2011: 225).

Mulyasana (2013: 178) argues that accountability is, financial management accountability in its implementation is required to provide accountability at the end of each budget with the issuance of funds during the fiscal year. So accountability is a person's condition that is judged by others because of the quality of his performance in accomplishing tasks to achieve the goals he is responsible for. According to Herbert, Killough, and stretss in Waluyo (2017: 197), the management of an organization must be accountable for: a). Determining the right goals; b). Develop the standards required for the achievement of the stated objectives; c). Effectively promote the application of standards; d). Developing organizational and operating standards economically and efficiently.

\section{Framework}

This study took four variables to be studied namely organizational commitment, microfinance accountability and poverty. In this study, the variables are divided into two groups namely the oxogenous variables in this case are Poverty and endogenous variables in this case is organizational commitment, microfinance and accountability. The deductive process in this research is identification of problem, premise and hypothesis, while identification of problem with case study at farmer group of North coast of West Java (Bekasi, Karawang, Subang, Indramayu and Cirebon).

The research method used in this research is survey method with causal approach to analyze the influence between variables using Structural Equation Model (SEM) which is run through AMOS 20 as its analysis tool. 
Respondents used amounted to 320 people. This research was conducted at farmer group of North coast area of West Java (Bekasi, Karawang, Subang, Indramayu and Cirebon).

Theoritical Model Research

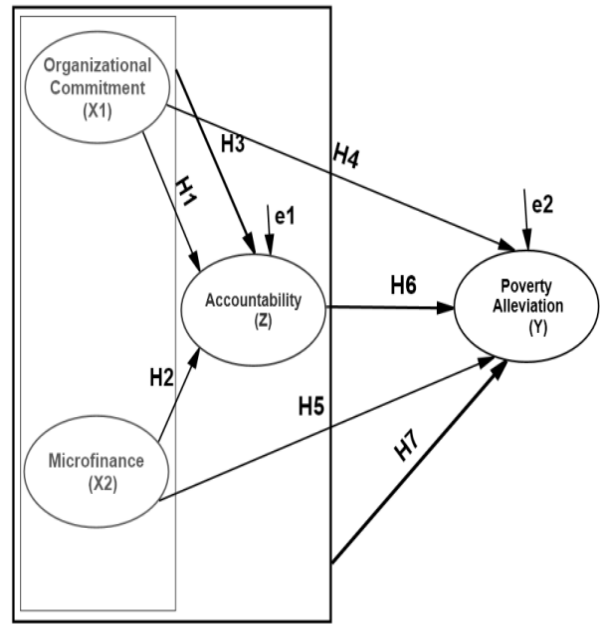

Figure 1. Theoretical Model Research

\section{DISCUSSION}

Testing Structural Equation Model (SEM)

Full Model 1

Structural standardized Value

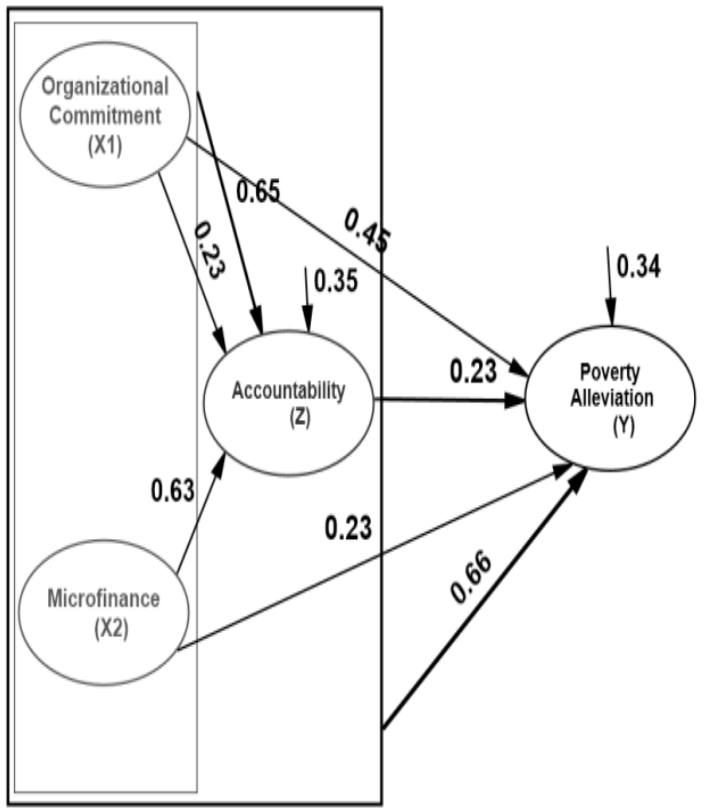

Figure 2 Calculation Results Structural Equation Model (Standardized Model)
Full Model 2

Structural Critical ratio / t Value

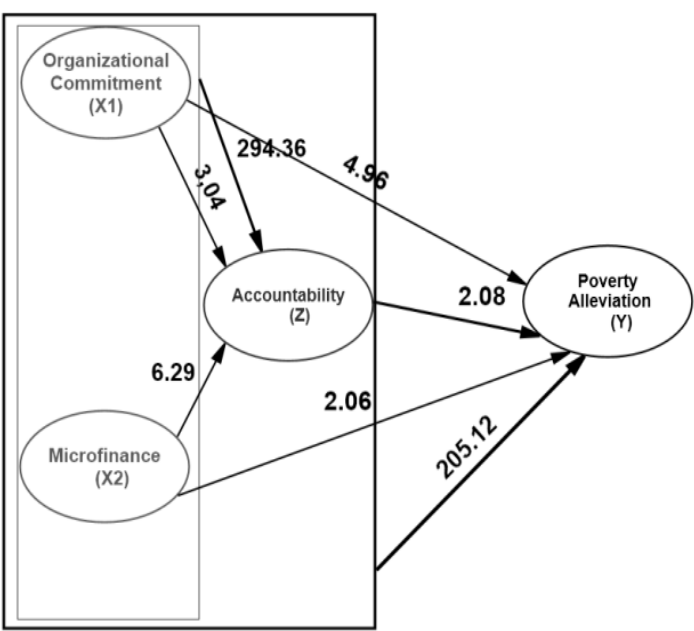

Figure 3 Calculation Results Structural Equation Model $(\mathrm{t}$-value model)

Table 1. : Results of the Feasibility Model Testing Structural Equation Model (SEM)

\begin{tabular}{|c|c|c|c|}
\hline $\begin{array}{l}\text { Goodness of } \\
\text { Fit Indeces }\end{array}$ & Cut-Off Value & Hasil & $\begin{array}{l}\text { Evaluasi } \\
\text { Model }\end{array}$ \\
\hline Chi-square & $<$ & 1819.92 & Good \\
\hline Propability & $\geq 0.05$ & 0.000 & Good \\
\hline RMSEA & $\leq 0,08$ & 0,071 & Good \\
\hline GFI & $\geq 0,90$ & 0,077 & $1 \quad$ Margina \\
\hline RMR & $\leq 0,05$ & 0,070 & Margina \\
\hline CMIN/DF & $\leq 2,00$ & 0,696 & Good \\
\hline IFI & $\geq 0.90$ & 0,89 & $1 \quad$ Margina \\
\hline CFI & $\geq 0.95$ & 0,89 & $1 \quad$ Margina \\
\hline
\end{tabular}

Judging from the results of calculations with SEM, the seven variables have a good goodness of fit, so it can be forwarded for testing the hypothesis that has been determined. 


\begin{tabular}{|c|c|c|c|c|c|}
\hline $\begin{array}{l}\text { Hypothes } \\
\text { is }\end{array}$ & Description & $\begin{array}{l}\text { Decisi } \\
\text { on }\end{array}$ & C.R. & $\begin{array}{l}S . M . \\
C\end{array}$ & $\begin{array}{l}\text { Conclusio } \\
\mathrm{n}\end{array}$ \\
\hline $\mathrm{H}_{1}$ & $\begin{array}{l}\text { There is a significant } \\
\text { effect of commitment } \\
\text { organization's of the } \\
\text { accountability }\end{array}$ & $\begin{array}{l}\text { Suporti } \\
\text { ve }\end{array}$ & 3.04 & - & $\begin{array}{l}\text { Direct } \\
\text { Effect }\end{array}$ \\
\hline $\mathrm{H}_{2}$ & $\begin{array}{l}\text { There is a significant } \\
\text { influence micro finance } \\
\text { of the accountability }\end{array}$ & $\begin{array}{l}\text { Suporti } \\
\text { ve }\end{array}$ & 6.29 & - & $\begin{array}{l}\text { Direct } \\
\text { Effect }\end{array}$ \\
\hline $\mathrm{H}_{3}$ & $\begin{array}{l}\text { There is a significant } \\
\text { effect of commitment } \\
\text { organization's and } \\
\text { microfinance together to } \\
\text { the accountability }\end{array}$ & $\begin{array}{l}\text { Suporti } \\
\text { ve }\end{array}$ & - & $\begin{array}{l}294.3 \\
6\end{array}$ & $\begin{array}{l}\text { Direct } \\
\text { Effect }\end{array}$ \\
\hline $\mathrm{H}_{4}$ & $\begin{array}{l}\text { There is a significant } \\
\text { effect of commitment } \\
\text { organization's on the to } \\
\text { the proverty alleviation }\end{array}$ & $\begin{array}{l}\text { Suporti } \\
\text { ve }\end{array}$ & 4.96 & - & $\begin{array}{l}\text { Direct } \\
\text { Effect }\end{array}$ \\
\hline $\mathrm{H}_{5}$ & $\begin{array}{l}\text { There is a significant } \\
\text { effect of the c } \\
\text { microfinance for the } \\
\text { proverty alleviation }\end{array}$ & $\begin{array}{l}\text { Suporti } \\
\text { ve }\end{array}$ & 2.06 & - & $\begin{array}{l}\text { Direct } \\
\text { Effect }\end{array}$ \\
\hline $\mathrm{H}_{6}$ & $\begin{array}{l}\text { There is a significant } \\
\text { effect of accountability } \\
\text { on the to the proverty } \\
\text { alleviation }\end{array}$ & $\begin{array}{l}\text { Suporti } \\
\text { ve }\end{array}$ & 2.08 & - & $\begin{array}{l}\text { Direct } \\
\text { Effect }\end{array}$ \\
\hline $\mathrm{H}_{7}$ & $\begin{array}{l}\text { There is a significant } \\
\text { effect of commitment } \\
\text { organization's, } \\
\text { microfinance and } \\
\text { accountability togetherto } \\
\text { the proverty alleviation }\end{array}$ & $\begin{array}{l}\text { Suporti } \\
\text { ve }\end{array}$ & - & $\begin{array}{l}205.1 \\
2\end{array}$ & $\begin{array}{l}\text { Direct } \\
\text { Effect }\end{array}$ \\
\hline
\end{tabular}

Hypothesis Testing Results

Table 2. : Results of Hypothesis Testing

\section{Result Analysis}

4.1. The influence of organizational commitment to accountability

Estimate standardized regression value is 0.23 or $23 \%$. Based on Critical Ratio / CR value of influence of organizational commitment to accountability is $3.04>2$, so it can be said significant, so partially organizational commitment has significant effect on accountability, the better the accountability of farmer groups in the north coast of West Java

\subsection{The influence of microfinance on accountability}

Estimate standardized regression value is 0.63 or $63 \%$. Based on Critical Ratio / CR value of microfinance effect on accountability is $6.29>2$, so it can be said significant, so partially microfinance has significant effect on accountability, meaning that the better the microfinance the better accountability of farmer group of north coast region of West Java

\subsection{The influence of organizational commitment and microfinance together on accountability}

Influence of variable influence of organizational commitment and microfinance variable together to accountability variable is equal to: $0.65 \times 100 \%=65 \%$, the rest of $35 \%$ influenced by other factors. At the value of $\mathrm{F}$ arithmetic greater than the value of $\mathrm{F}$ table that is equal to 294.36> 3.02, so the value of $P$ arithmetic obtained from the value of $\mathrm{P}$ table $0.000<0.05$. Thus, accountability of farmer groups in the north coast of West Java is positively influenced by organizational commitment and microfinance

\subsection{Influence of organizational commitment to poverty alleviation}

Estimate standardized regression value is 0.45 or $45 \%$. Based on Critical Ratio / CR value of influence of organizational commitment to poverty alleviation is $3.04>2$, so it can be said significant, so partially organizational commitment has a significant effect on poverty alleviation, meaning that the better commitment the better the poverty alleviation program of farmer groups in the north coast of West Java

\subsection{Effect of microfinance on poverty alleviation}

Estimate standardized regression value is 0.23 or $23 \%$. Based on Critical Ratio / CR value of microfinance effect on poverty alleviation is equal to $6.29>2$, so it can be said significant, so partially microfinance have a significant effect on poverty alleviation, meaning that the better microfinance well also poverty alleviation program farmer group of north coast region of West Java

\subsection{The effect of accountability on poverty alleviation}

Estimate standardized regression value is 0.23 or $23 \%$. Based on Critical Ratio / CR value of accountability effect on poverty eradication is $2.08>2$, so it can be said significant, so partially accountability significantly influence poverty alleviation, meaning that the better the accountability, the more improve poverty alleviation of farmer groups in the north coast of West Java

\subsection{The influence of organizational commitment, microfinance and accountability together against poverty alleviation}

The influence of organizational commitment variable, microfinance variable and accountability variable together with poverty alleviation are: $0.66 \times 100 \%$

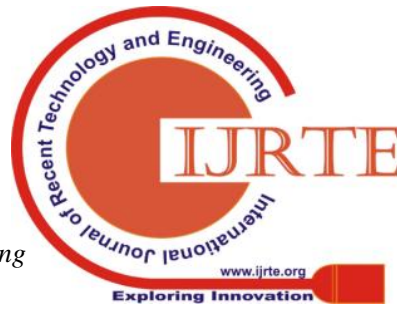


$=66 \%$, the rest of $34 \%$ is influenced by other factors. At the value of $\mathrm{F}$ arithmetic greater than the value of $\mathrm{F}$ table that is equal to 205.12> 2.63, so the value of $\mathrm{P}$ arithmetic obtained from the value of $\mathrm{P}$ table $0.000<0.05$. Thus the poverty alleviation of farmer groups in the north coast of West Java is positively influenced by organizational commitment, microfinance and accountability

\section{CONCLUSION}

1. Partial organizational commitment has a positive and significant impact on accountability. This indicates that the organization's commitment to the farmer group is better then it will further improve the responsible management in developing the business

2. Microfinance partially has a positive and significant effect on accountability. This indicates that the management of microfinance owned by members the better it will further enhance the development of business accountable in poverty alleviation programs

3. Organizational commitment and microfinance, simultaneously have a positive and significant impact on accountability. Of the two variables when viewed partially, it turns out the organizational commitment that has the most significant effect on accountability. This means that the better the organization's commitment the better the accountability. And silently, the better the organization's commitment and microfinance will increase accountability

4. Organizational commitment has a significant effect on poverty alleviation. This indicates that the better the organization's commitment will further enhance poverty alleviation programs.

5. Microfinance has a significant effect on poverty alleviation. This indicates that the better the microfinance the more will increase poverty alleviation programs.

6. Accountability has a significant effect on poverty alleviation This shows that with better accountability it will further improve poverty alleviation programs.

7. Micro finance organizational commitment and accountability, jointly affect poverty alleviation. Of the three variables when viewed partially, it turns out the organizational commitment that has the most significant effect on organizational performance. This means that the better the organizational commitment the better the poverty alleviation program

\section{Theoretical Implications}

\subsection{The effect of accountability on poverty alleviation}

Judging from the structural equations of the full model (Standardized Model) shows that organizational commitment is proven to influence accountability and poverty alleviation. this is in line with the results of Wijono's research, et al., 2017, (1993) that Commitment means more involving an active relationship and a desire to make a meaningful contribution to the organization. A significant contribution in financial management is to generate accountability and control all wealth in the hope of poverty.

\subsection{Microfinance}

Viewed from the structural equations of the full model (Standardized Model) showed that micro finance proved able to influence accountability and poverty alleviation. Accordingly, it is also in accordance with the research undertaken by Yopi et. al 2011 Microfinance shows that the higher level of capital suitability has a greater positive and significant influence on accountability thus to improve accountability, management needs to balance the real-time benefits between timely reporting and reliable information provision in capital in terms of effectiveness will be better in the relationship of attainment of the degree of life which is better optimally.

\subsection{Accountability}

Judging from the structural equations of the full model (Standardized Model) shows that accountability is proven to affect the quality of poverty alleviation. this is in line with Hassan 2006's research results. Accountability suggests being implemented and not undermined by members, as well as political interference in these activities ensuring that everything done ensures accountability. The effect of accountability can have a positive effect on poverty alleviation.

\subsection{Managerial Implications}

Based on the third hypothesis, there is a significant influence that accountability will increase if employees are highly committed to the organization is demonstrated by integrated and integrated capital management, understand the objectives of accountability as an organizational management framework, understand the function of accountability as the implementer of monitoring and evaluation supported by microfinance which is well ordered, so that capital can meet or facilitate the needs of farmer group businesses will progress significantly forward if this is demonstrated by implementation as a responsible shared goal.

Based on the seventh hypothesis, there is a significant influence that accountability will increase if employees have high commitment in this organization is shown by integrated and integrated capital management, understand the purpose of accountability as the organizational management framework, understand the function of accountability as the implementer of monitoring and evaluation supported by microfinance well organized, so that poverty alleviation will decrease significantly if this is demonstrated by implementation as a common goal to get a better life, especially in fulfilling primary needs.

\subsection{Suggestions}

1. Organizational commitment that has the lowest average value is in the ability of personnel or members who work on activities to achieve the objectives set by the leadership of farmer groups, by providing support to the activities of achieving the goals of accountability, so that will improve the life of members of the group. 
2. Microfinance that has the lowest average value is the lack of capital represents a strong influence on life expectancy. To increase the achievement of capital is required to have the ability to understand the capital Thus the use of capital will reflect a good effort in increasing revenue or income from the business run.

3. Accountability that has the lowest average score is the lack of groups conveying the message that ethical values and integrity, the sympathetic attitude of the leader to the problem or difficulty (empathy) to solving personal problems faced by members. This will promote leadership in instilling ethical values and organizational integrity in raising capital responsibly, which should not be compromised.

4. Poverty alleviation with the lowest average is in terms of planning and scope, poverty alleviation within farmer groups should be established by means of management policies that give full access to poor members to review and evaluate policies, plans, activities to achieve business goals that will be run well, so that will improve tarap life of the poor who in facilitation in the group.

\subsection{Limitations of Research and Advanced Studies}

There are many other aspects that can be used as research variables. So as to enable the findings in this study there are still limitations. These limitations include:

1. The first limitation: This study uses questionnaires as an instrument to collect data. Factors of respondent's psychological situation and condition are very influential when giving answer to the proposed statement, then it is possible to produce less data describing the actual situation and condition.

2. The second limitation: this study only uses seven variables (organizational commitment, microfinance, accountability) to know and measure poverty alleviation, whereas according to the researcher there are other factors / variables that also allegedly contributed or influenced poverty. As for other variables in the intent among others are: leadership style, communication style of leadership, professionalism and education and training

3. The third limitation: This study was conducted on the north coast of West Java. It should be done wider and more.

4. In relation to point three above, further research that researchers can recommend is as follows:

(a) The research is conducted at the level of the territory (Province) of all existing Ministries and Local Government either level one or level two.

(b) Research conducted at National level

The study was conducted using different analysis methods such as SEM analysis using lisrel, PLS, SPSS, Path and others

\section{CONCLUSIONS AND SUGGESTIONS}

\subsection{Conclusion}

This research is designed to know whether organizational commitment, microfinance, accountability are some factors influencing poverty alleviation. Therefore based on the results of research it can be drawn conclusion as follows:

There are positive and significant influences of organizational commitment, microfinance, accountability to poverty alleviation of North Java coastal farmer group.

\subsection{Suggestion}

Based on the results of research that has been done, researchers put forward some suggestions for further research, as follows:

For organizational commitment can be done by increasing organizational commitment is done with a more participative cultural approach of group members. For microfinance can be improved by fulfilling the biological needs through salary, wages, or benefits and health needs. As for accountability can be improved by teaching to delegate tasks so as not to pile up on one person alone, create a structured work plan, and hold togetherness activities to establish communication so that no increase in the responsibilities of the members of farmer groups.

Ethical clearance - Not required

Source of funding- Self

Conflict of Interest - Nil

\section{References}

[1] Anonim. 2011. Poverty Line Increases 10.3\% Last Year. Bisnis Indonesia, Sunday, July 3, 2011. Jakarta. http://www.bisnis.com/ekonomi/ makro / 29537-line-povertyrise-103-a-year-last.

[2] Armendariz, Beatriz dan Sarah Tsien. A Case for Successful Microfinance Programs in Cina. Paper for The 5th Conference on Global Economic Analysis, Taipeh, Taiwan. 5-7 Juni 2002. Taiwan, 2002.

[3] Ashari. Potential of Micro Finance Institution (MFI) in Rural Economic Development and Development Policy. Journal of Agricultural Policy Analysis, Volume 4 No. 2, June 2006: 146164. Indonesian Center for Agriculture Socio Economic and Policy Studies. Bogor,2006.

[4] Chambers. 2013. Rural Development Start From Backward.Jakarta: LP3ES Cotter, David A. 2012. Poor people in poor places: Local opportunity structures and household poverty, Colquitt Jason A. Jeffry A. Lepine dan Michael J. Wesson 2009; Organiztional Behavior, Mc Graw - Hill Irvin

[5] Hassan, MD. Mahmudul. Institutional Transformation of PovertyFocused Microfinance Institutions in Bangladesh, Nepal, and Malaysia. Universiti Sains Malaysia. Malaysia, 2006.

[6] I Komang Adi Wirawan, 1 Ketut Sudibia dan Ida Bagus Putu Purba dharmaja The Effect of Revolving Fund Assistance, Working Capital, Location of Marketing and Product Quality To SME Industry Sector Revenue In Denpasar-Bali. ISSN: 2337 3067 E-Journal of Economics and Business Udayana University 401 (2015): 01-21

[7] Kementerian Koperasi dan UKM. 2009Development of Micro Small Medium 
Enterprise (UMKM) and Large Business (UB) Year 2005-2009.. Jakarta

[8] Statistics of Small and Medium Enterprises Tahun 2007-2008. Jakarta, 2009.

[9] Kementerian Pertanian. General Guidelines for Rural Agribusiness Development (PUAP).. Jakarta, 2010.

[10] Khandker S.R. "Micro-finance and poverty: evidence using panel data from Bangladesh". World Development Vol.31 no. 3 pp.647$665,2003$.

[11] Kompas. 2011. Enam Tantangan Lembaga Kredit Mikro. Kompas, Rabu, $26 \quad$ Januari 2011. Jakarta. http://nasional.kompas.com/read/2011/01/26/ 14240329.

[12] Batas Kemiskinan Versi BPS Naik. Kompas, Minggu, 3 Juli 2011. Jakarta.http://cetak.kompas.com/read/2011/07/02/02154882/Batas. Kemiskinan.Versi.BPS.Naik.

[13] Mulyasana, Dede. Pendidikan Bermutu dan Berdaya Saing Tinggi, PT.Remaja Rosdakarya Bandung:, 2013.

[14] Minarti, Sri., Manajemen Sekolah Mengelola Lembaga Pendidikan Secara, 2011.

[15] Mandiri,: Ar-Ruzz Media Yogyakarta

[16] Waluyo, Manajemen Publik,: Mandar Maju, Bandung, 2007.

[17] Wijono, W., Pemberdayaan Lembaga Keuangan Mikro sebagai Salah Satu Pilar Sistem Keuangan Nasional. Pusat Pengkajian Ekonomi dan Keuangan. Badan Pengkajian Ekonomi, Keuangan dan Kerjasama Internasional, 2017.

[18] Wibowo., Performance Management, Jakarta: Raja Grafindo Persada, 2007.

[19] Yopi Saleh dan Yayat Hidayat, Strategi Pengembangan Lembaga Keuangan Mikro, 2011.

[20] Mendukung Pengentasan Kemiskinan Di Perdesaan Jurnal Ilmu ilmu Pertanian VOL. 7. NO. 1, 2011: HAL 66 - 81

[21] Arif, Bahtiar, Muchlis, Iskandar; Government Accounting. Akademia Jakarta, 2009.

[22] Arter, D.R.; Audit Quality to Improve Performance , ASQC Qualitas Press, Wisconsin, Amerika Serikat, ISBN 0-87389-057-4, 2009.

[23] BPKP. Performace Bugdeting Guideliines (Revisi), 2010. <http://www.bpkpp.go.id

[24] David, N and Hayman, Public Finance: A Contemporary Application of Theory to Policy Sevent Edition, Orlando USA; The Dryden Press, 2009.

[25] Mahsum Mohamad dan Mardiasmo; Measurement of Public Sectore Performance. Yogyakarta BPFE, 2009.

[26] Mardiasmo, Outonomy and Regional Financial Management , Ed. II, Yogyakarta: Andi Yogyakarta, 2009.

[27] Mayer J.P Allen NJ \& Smith C.A; "Commitment to Organizations and Occupation : Extention and Test of Three Component Conceptualization to Performace", Journal of Applied Psychology, Vol 78, No 4, P; 538-551, 1993.

[28] Moeller Robert; Brink's Modern Internal Auditing. John Wiley and Sons. Inc. Hoboken, New Jersey Published Canada, 2009.

[29] Muhlis, Syarifuddin dan Mediaty; "Effect Of Participation On Budget Preparing To Performance Of Local Government Officials With Organizational Culture And Organizational Commitment As A Moderator (Case Study On Gevernment of Barru Regency, SulSel)". Issue 11 Euro Journals Publishing, Inc, 2010.

[30] Muslimin; Accountability and Financial reporting of performance based institutions. Bandung IKAPI, 2011.

[31] Nainggolan Adolpino; Pengaruh komitmen organisasi, struktur pengendalian intern, audit internal terhadap pencapaian kinerja perusahaan. Jurnal Ekonomi, Manajemen dan Akuntansi, Universitas Budi Luhur, 2009.

[32] Otley D.T; "Budget Use and Managerial Performance". Journal of Accounting Research Spring. pp. 122-149, 1987.

[33] Sukmalana Soelaiman; Work Management. Intermedia Personalia Utama 2009.

[34] Sumarno Sonny; Financial Accounting Government Geraha Ilmu 2010.

[35] Witt. L A; "Reactions to Work Assignments as Predictors of Organizational Commitment: The Moderating Effect of Accupational Identification". Journal of Business Research 26, 8196, 2008. 